\title{
MENINGKATKAN AKUNTABILITAS BADAN USAHA MELALUI SISTEM INFORMASI PEMBELIAN BARANG
}

\author{
1) Nofiyani \\ 1) Program Studi Sistem Informasi, Fakultas Teknologi Informasi \\ Universitas Budi Luhur \\ JI. Ciledug Raya, Petukangan Utara, Jakarta Selatan 12260
}

\begin{abstract}
Abstrak : Pembelian merupakan transaksi yang dilakukan untuk pengadaan barang atau jasa. Untuk menunjang kegiatan transaksi tersebut diperlukan pencatatan dari hasil transaksi. Sistem akuntansi yang baik dapat mendukung efektivitas pengendalian manajemen serta meminimalisir penyelewengan yang mungkin terjadi. Sistem akuntansi pembelian dibangun untuk mempermudah proses pembelian barang atau jasa. Dimana tidak terbatas pada laporan pertanggungjawaban, tetapi juga mencakup aspek kemudahan dalam mendapatkan informasi. Sistem informasi yang mendukung dalam melakukan pengolahan data menggunakan teknologi informasi akan meningkatkan kinerja suatu badan usaha. Terdapat tiga tahapan dalam pengembangan sistem dengan menggunakan model rapid application development (RAD) diantaranya perencanaan kebutuhan, mendesain sistem dan implementasi sistem. Dan dihasilkan dua form sebagai pencatatan data barang dan transaksi pembelian. Tiga laporan sebagai pengawasan dan pertanggungjawaban akuntabilitas diantaranya laporan transaksi pembelian barang, laporan persediaan barang dan laporan harga per item barang per periode transaksi.
\end{abstract}

Kata Kunci : Pembelian, Sistem Akuntansi, Sistem informasi, Rapid Application Development.

Abstract: Purchases are transactions made for the procurement of goods or services. To support these transactions, it is necessary to record the results of the transactions. A good accounting system can support management control and minimize possible fraud. Purchase accounting system built to simplify the process of purchasing goods or services. Not limited to accountability reports, but also includes various conveniences in obtaining information. Information systems that support data processing using information technology will improve the performance of a business entity. There are three stages in system development using the rapid application development (RAD) model, including requirements planning, system design and system implementation. And produced two forms as data recording of goods and purchase transactions. Three reports as supervision and accountability of goods purchase transaction reports, inventory reports and price reports per item of goods per transaction period.

Keywords: Purchasing, Accounting System, Information system, Rapid Application Development.

\section{PENDAHULUAN}

Pembelian merupakan transaksi yang dilakukan untuk pengadaan barang atau jasa, yang bertujuan untuk dijual kembali ataupun untuk digunakan sendiri. Untuk menunjang kegiatan transaksi pembelian diperlukan formulir dan dokumen serta pencatatan dari hasil transaksi yang tertera dalam formulir dan dokumen [1]. 
Untuk menciptakan kegiatan operasional yang efektif, maka harus diimbangi dan dibutuhkan sebuah sistem akuntansi [2]. Sistem akuntansi yang baik dapat mendukung efektivitas pengendalian manajemen suatu badan usaha serta meminimalisir penyelewengan yang mungkin terjadi. Dengan adanya pengendalian manajemen tersebut akan membentuk efektivitas sumber daya yang dimiliki [3]. Maka dapat disimpulkan bahwa sistem akuntansi pembelian dibangun untuk mempermudah proses pembelian barang atau jasa [2]. Media pertanggungjawaban akuntabilitas tidak terbatas pada laporan pertanggungjawaban, tetapi juga mencakup pada aspek kemudahan dalam mendapatkan informasi, sehingga akuntabilitas dapat tumbuh pada lingkungan yang mengutamakan keterbukaan sebagai landasan pertanggungjawaban [4]

sistem informasi yang mendukung dalam melakukan pengolahan data menggunakan teknologi informasi akan meningkatkan kinerja suatu badan usaha. Dengan adanya sistem informasi data dapat diolah dan disimpan dengan mudah sehingga dapat menghasilkan informasi yang tepat dan akurat serta dapat meminimalisir terjadinya kesalahan pencatatan dan menghindari penyimpangan oleh oknum yang tidak bertanggung jawab [5]. Dengan peningkatan akuntabilitas dalam penyajian data baik kepada pelanggan maupun pemilik usaha / badan usaha diharapkan dapat meningkatkan daya saing dan ketahanan suatu badan usaha. Sehingga bisnis akan tetap kuat dalam setiap kondisi [4].

\section{KAJIAN PUSTAKA DAN LANDASAN TEORI}

Sistem informasi adalah suatu kombinasi teratur dari orang-orang, hardware,
Jurnal IImu Komputer dan Informatika Vol 2 No 2

p-ISSN: 2776-7418 e-ISSN: 2746-508X

software, jaringan komunikasi dan sumber daya data yang mengumpulkan, mengubah dan menyebarkan informasi dalam sebuah organisasi. Salah satu fungsi sistem informasi adalah untuk meningkatkan aksesibilitas data yang ada secara efektif dan efisien kepada pengguna, tanpa dengan perantara sistem informasi [6].

Menurut Kamus Besar Akuntansi pengertian pembelian adalah sebagai berikut: "Perkiraan yang digunakan dalam sistem pembelian berkala untuk mencatat biaya semua barang yang dibeli untuk dijual kembali" [7].

sistem akuntansi terdiri dari metode pencatatan yang digunakan untuk mengidentifikasi, merangkai, menganalisis, menggolongkan, mencatat, dan melaporkan transaksi yang telah dilakukan serta memelihara akuntabilitas aktiva dan kewajiban yang terkait [3]. Menurut Mulyadi sistem akuntansi adalah organisasi formulir, catatan dan laporan yang dikoordinasi sedemikian rupa untuk menyediakan informasi keuangan yang dibutuhkan oleh manajemen guna memudahkan pengelolaan perusahaan.

\section{METODE}

Metode penelitian dalam penelitian ini adalah penelitian kualitatif, dimana data diperoleh dengan:

1. Melakukan wawancara untuk mendapatkan data yang lebih lengkap.

2. Melakukan observasi secara langsung untuk mengetahui prosedur sistem yang sedang berjalan.

3. Melakukan analisa terhadap dokumentasi yang telah dikumpulkan.

Metode pengembangan sistem dalam penelitian ini adalah Model Rapid Application Development (RAD) yang terdiri dari tiga tahapan: 
1. Perencanaan Kebutuhan, pada tahapan ini pengguna dan analis akan mengidentifikasi permasalahan dan informasi yang dibutuhkan guna menyelesaikan permasalahan tersebut.

2. Mendesain Sistem, pada tahap ini analis dan programmer akan merancang representasi visual desain dan pola kerja dari sistem yang akan dibangun serta melakukan perbaikan berdasarkan masukan dan respon dari pengguna.

3. Implementasi, yang merupakan tahap pengembangan yang dilakukan oleh programmer berdasarkan desain sistem yang telah disetujui oleh pengguna dan analis. Dan sebelum diaplikasikan untuk mengetahui apakah masih ada kesalahan atau tidak, harus dilakukan uji coba terlebih dahulu.

\section{HASIL DAN PEMBAHASAN}

Perencanaan Kebutuhan

a. Proses Bisnis Usulan:

1. Pendataan Barang

Akan dilakukan setiap ada barang/item baru yang dibeli, petugas akan melakukan pendataan dengan menginputkan data barang dalam form entri data barang. Sedangkan untuk barang/item lama harga beli dan stok barang akan otomatis terinput saat dilakukan pendataan transaksi pembelian barang.

2. Pendataan Transaksi Pembelian Barang

Setiap ada transaksi pembelian barang, petugas akan melakukan pendataan dengan menginputkan data pembelian barang dalam form entri pembelian barang.

3. Pembuatan Laporan

Pembuatan laporan dilakukan setiap akhir bulan atau untuk pertanggung jawaban ke pemilik usaha yang terdiri dari laporan transaksi pembelian barang, laporan persediaan barang, laporan harga per item barang per periode transaksi.

b. Kebutuhan Informasi

Tabel 1. Kebutuhan Informasi

\begin{tabular}{|c|c|c|c|}
\hline $\begin{array}{l}\mathrm{N} \\
\mathrm{O} .\end{array}$ & Informasi & Tujuan & Frekuensi \\
\hline 1. & $\begin{array}{l}\text { Laporan } \\
\text { transaksi } \\
\text { pembelian } \\
\text { barang untuk } \\
\text { mengetahui } \\
\text { rincian barang } \\
\text { yang sudah } \\
\text { dibeli }\end{array}$ & $\begin{array}{l}\text { Pemilik } \\
\text { Usaha }\end{array}$ & $\begin{array}{l}\text { Setiap } \\
\text { akhir } \\
\text { bulan }\end{array}$ \\
\hline 2. & $\begin{array}{l}\text { Laporan } \\
\text { persediaan } \\
\text { barang untuk } \\
\text { mengetahui } \\
\text { stok barang } \\
\text { yang dimiliki }\end{array}$ & $\begin{array}{l}\text { Pemilik } \\
\text { Usaha }\end{array}$ & $\begin{array}{l}\text { Setiap } \\
\text { akhir } \\
\text { bulan }\end{array}$ \\
\hline 3. & $\begin{array}{l}\text { Laporan } \\
\text { harga per item } \\
\text { barang per } \\
\text { periode } \\
\text { transaksi } \\
\text { untuk } \\
\text { mengetahui } \\
\text { naik turunnya } \\
\text { harga per item } \\
\text { barang per } \\
\text { periode } \\
\text { transaksi }\end{array}$ & $\begin{array}{l}\text { Pemilik } \\
\text { Usaha }\end{array}$ & $\begin{array}{l}\text { Setiap } \\
\text { akhir } \\
\text { bulan }\end{array}$ \\
\hline
\end{tabular}

c. Use Case Diagram

1. File Master

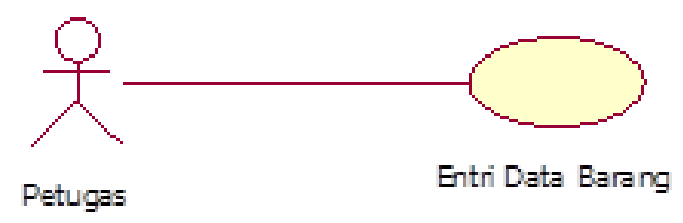

Gambar 1. Use Case Diagram File Master

2. Transaksi Pembelian Barang 


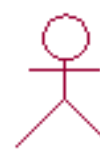

Petugas

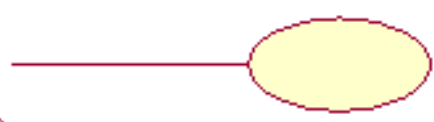

Entri Pembelian Barang

Gambar 2. Use Case Diagram Transaksi Pembelian Barang

3. Laporan

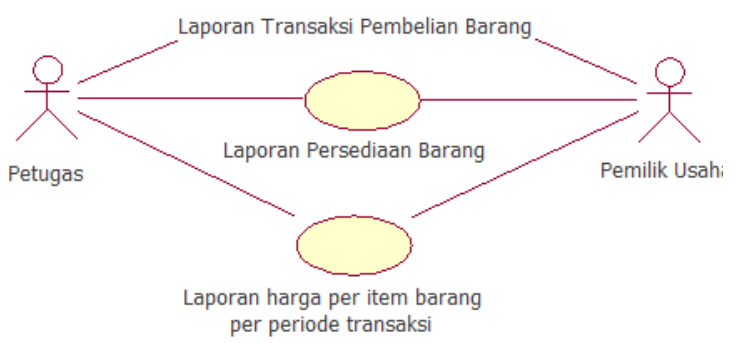

Gambar 3. Use Case Diagram Laporan

\section{Mendesain Sistem}

a. Desain Interface

1. Struktur Tampilan Menu

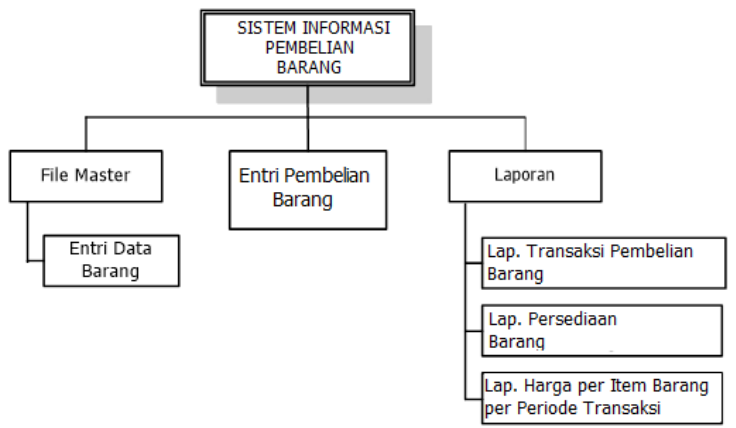

Gambar 4. Struktur Tampilan Menu

2. Tampilan Entri Data Barang

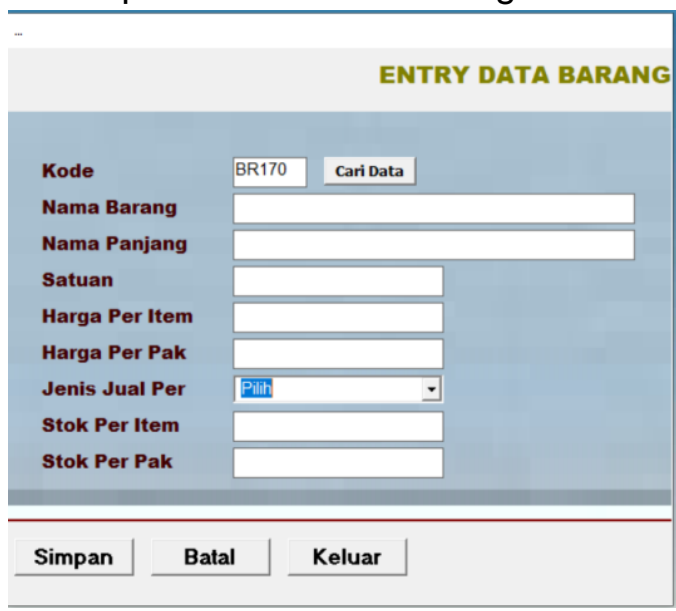

Gambar 5. Tampilan Entri Data Barang
Jurnal IImu Komputer dan Informatika Vol 2 № 2 p-ISSN: $2776-7418$ e-ISSN: 2746-508X

3. Tampilan Entri Pembelian Barang

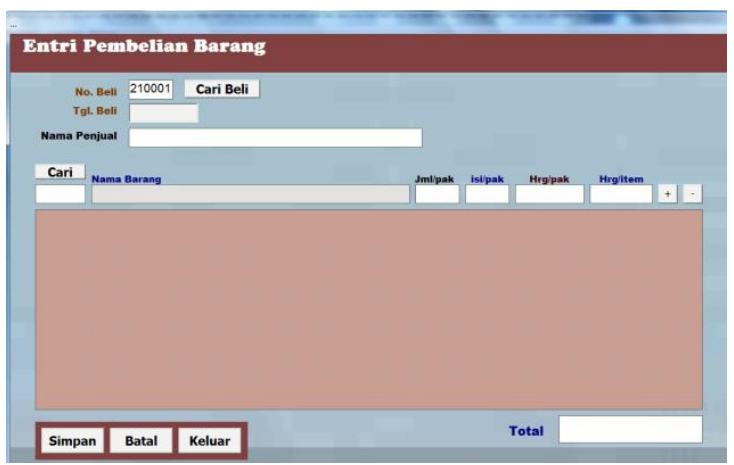

Gambar 6. Tampilan Entri Pembelian Barang

4. Tampilan Laporan Transaksi Pembelian Barang

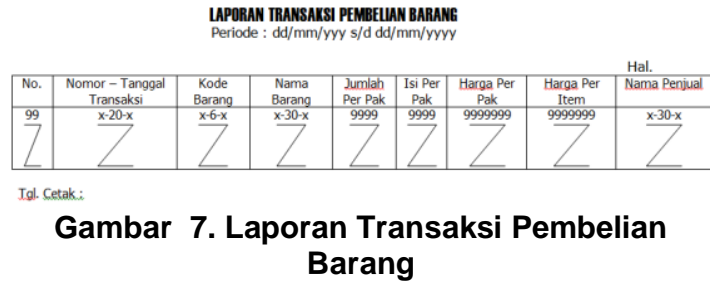

5. Tampilan Laporan Persediaan Barang

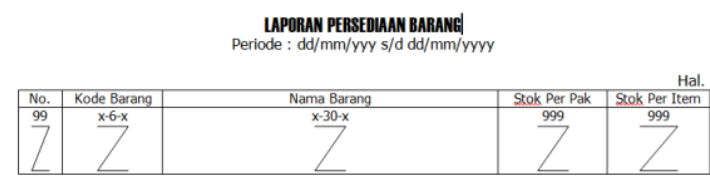

Gambar 8. Laporan Persediaan Barang

6. Tampilan Laporan Harga per Item Barang per Periode Transaksi

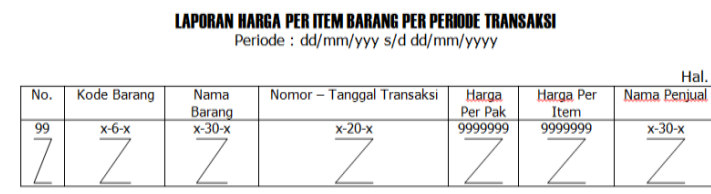

Tol. Cetak

Gambar 9. Laporan Harga per Item Barang per Periode Transaksi

\section{Implementation}

Tahapan dalam implementasi sistem diantaranya:

1. Mempersiapkan data-data yang dibutuhkan.

2. Mempersiapkan software yang akan digunakan.

3. Melakukan Instalasi software. 
4. Menentukan user yang akan menggunakan sistem.

5. Memberikan pelatihan kepada user bagaimana penggunaan sistem.

6. Sosialisasi kepada semua pihak yang terkait dengan sistem.

7. Melakukan uji coba sistem.

8. Melakukan evaluasi dan perbaikan jika ada kekurangan dalam sistem.

9. Membuat dokumentasi.

\section{KESIMPULAN}

Kesimpulan yang dapat diambil dari penelitian ini adalah

1. Terdapat 2 form yang dapat digunakan dalam pencatatan data barang dan transaksi pembelian, sehingga data dapat diolah dan disimpan dengan lebih mudah. Diantaranya entri data barang dan entri pembelian barang.

2. Terdapat tiga laporan sebagai pengawasan atau pengontrolan pemilik usaha serta sebagai acuan dalam pengambilan keputusan diantaranya laporan pertanggungjawaban akuntabilitas dari petugas/staff yaitu laporan transaksi pembelian barang untuk pertanggungjawaban rincian barang yang sudah dibeli atau pengeluaran yang telah dikeluarkan. Laporan persediaan barang untuk mengetahui stok barang yang dimiliki. Laporan harga per item barang per periode transaksi untuk mengetahui perbandingan naik turunnya harga per item barang per periode transaksi.

\section{REFERENSI}

[1] Indah, M. (2017). Analisis Sistem Dan Prosedur Akuntansi Pembelian Guna Meningkatkan Efektivitas Pembelian Rubber Seal. Jurnal Benefit Vol. 4 No. 1 Juli 2017. hal 15-28. https://journal.unita.ac.id/index.php/benefit /article/view/94 (Diunduh tanggal 29 November 2021).

[2] Valleria, C. N. (2018). Analisis Sistem Akuntansi Pembelian Barang Dagang. Skripsi. Tidak diterbitkan. Yogyakarta: Fakultas Ekonomi Universitas Sanata Dharma.

[3] Hendro, S. Dan Sulistyo (2016). Analisis Pelaksanaan Sistem Akuntansi Pembelian Untuk Meningkatkan Efektivitas Sistem Pengendalian Manajemen. Journal Riset Mahasiswa Akuntansi (JRMA) ISSN: 233756xx. Volume: $x x$, Nomor: $x x$. hal 1-14. https://ejournal.unikama.ac.id/index.php/jr ma/article/view/1217/954 (Diunduh tanggal 29 November 2021).

[4] Nofiyani (2020). Meningkatkan Pelayanan Dan Akuntabilitas Melalui Pengembangan Sistem Informasi Pada Administrasi Service Kendaraan Bermotor. Jurnal Teknologi Informasi) Vol.4, No.1, Juni 2020. hal 152-159. http://jurnal.una.ac.id/index.php/jurti/article /view/1293/1109 (Diunduh tanggal 29 November 2021).

[5] Nofiyani (2021). Implementasi Sistem Informasi Inventarisasi Barang Guna Pengendalian Internal. Indonesia Journal Information System (IDEALIS) Volume 4, Nomor 1, Januari 2021 ISSN 2684-7280 (online). hal 55-62. https://jom.fti.budiluhur.ac.id/index.php/ID EALIS/article/view/2775/1141 (Diunduh tanggal 29 November 2021).

[6] Elisabet, Y. A. Dan Rita, I. (2017). Pengantar Sistem Informasi. Yogyakarta: Andi.

[7] Dina, C. (2018). Tinjauan Pembelian Atas Prosedur Peralatan Kantor Pada Pt Deltra Wijaya Konsultan. Diploma thesis, Universitas Komputer Indonesia. 